\title{
Akateeminen kapitalismi ja kollektiivisuuksien paradoksaalisuudet tohtorikoulutuksessa
}

\author{
بैy \\ Hakkarainen, Hytönen, Makkonen \& Lehtonen ehdottivat \\ Aikuiskasvatuksessa 4/2013 “luonnontieteellisen”, niin sanotun \\ kollektiivisen mallin soveltamista kasvatustieteellisessä \\ jatkokoulutuksessa. Kirjoittajakollektiivi jatkaa keskustelua \\ akateemisen kapitalismin uhasta.
}

\begin{abstract}
"Siinä annetaan semmonen kuva, että millä tavalla mahdollisimman tehokkaasti kontrolloidaan tohtorituotantoa."

"Esitetä̈n malli sihen eli tavallaan valmiit asetelmat joiden kautta sosiaalistetaan valmiisiin vakiintuneisiin toimintatapoihin. Minimoidaan harhailua ja semmosta löytöretkeilyä. Tohtoriks kouluttautuminen ei voi olla ainoastaan noin vanhakantaselle oppimiskäsitykselle perustuva."
\end{abstract}

TÄMÄ TEKSTI SYNTYI, kun ryhmä Helsingin yliopiston yhteiskuntatieteellisen kasvatustieteen (Kasvatus, yhteiskunta ja kulttuuri eli KYK-painoalueen) nuorempia ja vanhempia tutkijoita kokoontui keskustelemaan ja kirjoittamaan kollektiivisen tutkimuk- sen tekemisestä. Kutsumme itseämme tässä tekstissä KYK-kollektiiviksi. Nauhoitimme keskustelumme ja käytämme sitä tuomaan julki ajatuksiamme kirjoittamisen ja tieteen tekemisen kollektiivisesta luonteesta. Tällä kollektiivisesti tuotetulla puheenvuorolla haluamme osallistua keskusteluun, jota Kai Hakkarainen, Kaisa Hytönen, Juho Makkonen ja Erno Lehtinen kävivät Aikuiskasvatus-lehdessä (4/2013) artikkelilla Kollektiivista mallia voidaan soveltaa kasvatustieteiden tohtorikoulutuksessa. Haluamme kommentoida paitsi kollektiivisuuden ilmenemistä tohtorikoulutuksessa, myös jatkaa keskustelua artikkelissa esiin tuodun akateemisen kapitalismin uhasta.

Kyseisessä artikkelissa ehdotettu "luonnontieteellisen”, kollektiivisen mallin soveltaminen kasva- 
tustieteellisessä jatkokoulutuksessa käytetyn "yksilöllisen” mallin sijaan herätti ryhmässämme kovasti keskustelua. Koimme mallissa esitetyn kollektiivisen ja yksilöllisen vastakkainasettelun yllättäväksi, koska olimme ajatelleet kollektiivisuudesta toisin. Aloimme pohtia, minkälaisiin ideoihin erottelu yksilöllisen ja kollektiivisen välillä perustuu ja minkälaisia vaikutuksia tällä erottelulla on akateemiselle työlle.

"Mä koko aika päädyin pohtimaan sitä, että mitä tehdään täällä yliopistolla, miks me ollaan täällä ja mikä on yliopiston pointti."

"Tossahan se yliopiston pointti [viittaa artikkeliin] tai sen tutkimuksen pointti on, että jo tiedetään mitä niinkun pitää tutkia ja ne on niitä legaaleja tutkimuskohteita ja ne on niitä mitä ne professorit on tehny."

"Ja sit se tieto jotenkin ihmeellisesti kumuloituu eli aika lineaarisesti se tuntuu etenevän."

Yhtältä ymmärrämme halun edistää niin sanottua kollektiivista mallia myös kasvatustieteellisessä tutkimuksessa. Toisaalta haluamme pohtia tarkemmin, miksi kollektiivinen malli pyritään tuomaan uutuutena kasvatustieteelliseen tutkimukseen. ${ }^{1}$ Näkemyksemme mukaan Hakkaraisen ym. esittämä kollektiivinen malli ei sovi yhteen sen kollektiivisuuden kanssa, jota on yhteiskuntatieteellisessä ja kasvatustieteellisessä tohtorikoulutuksessa sovellettu jo pitkään.

\section{KOLLEKTIIVISEN JA YKSILÖLLISEN VASTAKKAIN ASETTAMISEN ONGELMALLISUUS}

Hyödynnämme diskursiivis-dekonstruktiivista lähestymistapaa, jolla tarkastelemme mainittua diko- tomiaa yksilöllisen ja kollektiivisen mallin välillä. Dikotomioiden purkamisen lisäksi lähestymistapa kyseenalaistaa ja kritisoi länsimaista ajattelua hallinneita hierarkkisia vastakohtia sekä niiden ehdottomuutta, itsestäänselvyyttä ja luonnollisuutta (Brunila 2011; Brunila \& Ikävalko 2012; Guttorm 2014; Hakala 2007; ks. myös Derrida 1997; 2003). Vastakkainasettelut palvelevat joitain, yleensä auki puhumattomia tarkoituksia eivätkä ne koskaan esiinny puhtaina. Dekonstruktiivisessa hengessä etsimme artikkelista keskustelun aloitukseksi niitä oletettuja vastakohtia, joille malli perustuu (Taulukko 1).

Tulkintamme mukaan yksilöllinen malli näyttäytyy sellaisena, jossa tutkija toimii muusta tiedeyhteisöstä eristäytyneenä ja eristettynä ja on myös tuottamaton, kilpailukyvytön ja tehoton, päinvastoin kuin kollektiivisen mallin tutkija. Kollektiivisen mallin peruspiirteinä ovat vahva tutkimusjohtajakeskeisyys, yhteisjulkaiseminen kansainvälisissä tieteellisissä lehdissä sekä tietokäytäntöjen vertikaalinen ja horisontaalinen jakaminen. Väitöskirjaa tekevän tutkijan näkökulmasta nämä peruspiirteet puoltavat ajattelutapaa, jonka mukaan aloittelevien tutkijoiden ajatellaan omaksuvan akateemiset käytännöt vuorovaikutuksessa ohjaajan, muiden senioritutkijoiden ja vertaisten kanssa.

"Tällainen "kollektiivinen kirjoittaminen" nostaa
indeksejä, kasvattaa CV:tä ja näyttää tehokkaalta,
vaikka onkin vaikea sanoa, mikä yksittäisen kirjoit-
tajan osuus tekstissä on, tai onko sitä; mitä kukin
on tutkinut ja mitä osaa. Jos kyse on pitkälti strate-
gisesta CV:n ja indeksien kasvattamisesta, onko sil-
lä väliä? Mukaudummeko siihen, ja entä ne, jotka
eivät halua toimia niin?"

"Tällainen "kollektiivinen kirjoittaminen" nostaa indeksejä, kasvattaa CV:tä ja näyttää tehokkaalta, vaikka onkin vaikea sanoa, mikä yksittäisen kirjoittajan osuus tekstissä on, tai onko sitä; mitä kukin on tutkinut ja mitä osaa. Jos kyse on pitkälti strategisesta CV:n ja indeksien kasvattamisesta, onko sileivät halua toimia niin?"

Taulukko 1. Kollektiivinen ja yksilöllinen tohtorikoulutuksen malli.

\begin{tabular}{|l|l|}
\hline KOLLEKTIIVINEN MALLI & YKSILÖLLINEN MALLI \\
\hline - monimutkainen ajattelu & - yksinkertainen ajattelu \\
- kansainvälinen julkaiseminen & - henkilökohtaisen kokemuksen varassa tehty kansallinen julkaisu \\
- erikoistuminen & - ohjaaja-opiskelijasuhde ongelmallinen (heitteillejättö jopal \\
- vahvat verkostot & - heikot verkostot \\
- tiedon kumuloituminen & - tieto ei tieteellisesti relevanttia \\
- sosiaalistuminen & - yksin jääminen \\
- ytimessä & - laitamilla \\
\hline
\end{tabular}


"Jos se on niin, et koko tutkimusryhmä länttää nimensä sinne, ni siinä voi muodostua illuusio, et kaikki on osallistuneet ja yhteisesti ollaan tehty. Ja sit toisaalta luodaan kahtiajakoa, et jos joku kirjoittaa monografiaa ja siellä on vaan hänen nimi, niin hänhän ei ole sitten kenenkään kanssa keskusteluja käynyt."

"Jos meit kuitenkin arvioidaan yksilöinä jossain, mut sit meidän CV:t on täynnä semmosia artikkeleita, jossa me ei olla yksin kirjoitettu mitään ja jossa sitä mitä me ollaan oikeesti tehty, mitä me tiedetään ja minkä asiantuntija me ollaan ni eihän kukaan pysty arvioimaan sitä."

Sharon L. Nichols ja David C. Berliner (2007) ovat tuoneet esiin amerikkalaisia kansallisia testaamiskäytäntöjä (high-stakes testing) tarkastelevassa kirjassaan, miten indikaattorit voivat päätöksenteon välineinä mitata pikemmin itseään kuin ilmiötä, jota niillä yritetään mitata. He esittävät, että esimerkiksi opettajat ovat alkaneet keskittää valmentavaa opetusta niihin oppilaisiin, jotka ovat lähellä testien läpäisemisen rajaa. Samalla on unohdettu ne, jotka ovat tästä rajasta kaukana, sekä ne, jotka läpäisevät testin joka tapauksessa. Opetuksen logiikka alkaa näin noudatella mittariin sisältyvää koulujen keskinäisen kilpailun logiikkaa. Kyseinen testaaminen ja siitä johtuva kilpailu koulujen välillä voi johtaa taktikointiin, joka saa huijaamisen piirteitä. Testituloksilla kun on myös taloudellisia seurauksia kouluille. KYK-kollektiivissa käymässämme keskustelussa (ks. yllä oleva lainaus) nousikin esiin huoli siitä, että artikkelien tuottamisesta voi muodostua itseisarvoinen käytäntö ihmistieteisiin, jolloin tilastollisesta näkyvyydestä tulee keskeinen, tai pahimmillaan ainoa, maineen ja myös rahoituksen saannin perusta. Opimme monin tavoin hyödyntämään ja käyttämään hyväksi niitä järjestelmiä, jotka meitä määrittävät. Tällöin kyse ei enää välttämättä ole pelkästään tieteestä tai tutkimuksen tekemisestä, vaan tietyllä tiedepoliittisella ja markkinoituneella yliopistokentällä pärjäämisestä.

Hakkaraisen ym. (2013) ehdottamassa kollektiivisessa mallissa luodaan hierarkia arvokkaampana pidetyn artikkelimuotoisen väitöskirjan ja monografian välillä. Tällainen hierarkia peittää kuitenkin alleen sen, että myös monografian tekijät julkaisevat artikkeleita. Lisäksi monilla yhteiskuntatieteellisillä ja humanistisilla tutkimusaloilla ajatellaan väitöskirjatyötä edelleen monografioina (ks. Puuska \& Miettinen 2008). Myös kansainvälisesti tarkasteltuna arvostus artikkeliväitöskirjojen ja monografioiden välillä vaihtelee yliopistoittain. Kuitenkin väitöskirjan sisällön tulisi määrittää sen muotoa: joissain tutkimuksissa monografia on sopivampi, toisissa taas artikkelit sopivat paremmin (ks. esim. Valo 2013).

Opetusministeriön Julkaisukäytännöt eri tieteenaloilla -tutkimushankkeen raportin (Puuska \& Miettinen 2008) mukaan kasvaneista julkaisupaineista huolimatta erityisesti humanistiset alat erottautuvat edelleen poikkeuksellisen vahvalla yksin julkaisemisen traditiolla siitä huolimatta, että myös niiden piirissä tutkimusta tehdään yleisesti ryhmissä. Kuitenkin yhteisjulkaiseminen on lisääntynyt viime vuosina myös kasvatus- ja yhteiskuntatieteissä sekä humanistisen tutkimuksen piirissä, vaikka luonnontieteisiin verrattuna näillä aloilla yksin julkaiseminen on edelleen suosittua. Yhteiskuntatieteissä eri tieteenalojen väliset erot ovat kuitenkin hyvin suuret, ja esimerkiksi psykologia erottautuu luonnontieteitä muistuttavilla julkaisukäytännöillä. Raportissa näitä eri tieteenalojen välisiä eroja perustellaan etenkin sillä, millainen merkitys kirjoitustyöllä on koko tutkimusprosessissa: humanistisilla ja yhteiskuntatieteellisillä aloilla kirjoittaminen on keskeisessä asemassa koko tutkimusprosessin ajan. Luonnontieteissä kirjoittaminen on ensisijaisesti tutkimustulosten esittämisen väline. (Puuska \& Miettinen 2008.)

\section{AKATEEMINEN KAPITALISMI JA SEN TUOTTAMA SUBJEKTI}

"Se artikkelimalli ohjelmoi väistämättä siihen, että se hajoo enemmän, et mihinkään ei voi keskittyy kunnolla. Jos se on silleen, että siellä joku hanke ja johon vähän niinkun tarjotaan, et ota sä tää osio ja ota sä tää toinen osio, että kuinka syvälle voi päästä ylipäätään."

"Mä ajattelen, et se oli ylellisyyttä, et mä sain tehdä vielä monografiaa, et on saanu aikaa pyöritellä, jättää jäädä kesken moni asia." 
"Mut en mä ajattele, et artikkelien kirjoittaminen olis huono asia, se voi olla hyvä sen tutkimuksen kannalta, et se voi myös tehdä hyvää sille argumentille. Ehkä se on kysymys siitä, miten se kollektiivisuus toimii eikä niinkun onks se hyvä vai huono."

"Se on musta mielenkiintonen kysymys, et miten on päädytty siihen, et yhtäkkiä toi alkaa oleekki kaikilla tieteenaloilla se oikea tapa tehdä tutkimusta."

Akateemisella kapitalismilla on yhdysvaltalaisessa keskustelussa viitattu tiettyjen poliittis-taloudellisten prosessien tunkeutumiseen osaksi yliopistojärjestelmän toimintatapoja (Slaughter \& Leslie 1997). Yliopistossa akateeminen kapitalismi ja sen mukanaan tuomat markkinamaiset toimintatavat näkyvät yhtäältä ulkopuolisen rahoituksen sekä yliopistossa tehtävän tutkimuksen ulkopuolisen arvioinnin lisääntymisenä, toisaalta paineena lisätä akateemisen työn tuottavuutta sekä sen kaupallisia hyödyntämismahdollisuuksia. Akateemisen kapitalismin aikakaudella tutkijat ovat kiinnittäneet huomiota myös kasvaneeseen pyrkimykseen yksityistää julkista tietoa muun muassa patentointitoiminnan ja tutkimusten tuotteistamisen muodossa. Myös yritysyhteistyön korostuminen, ulkopuolisella rahoituksella rahoitetut professuurit, lukukausimaksut ja kasvanut varainkeruutoiminta ovat merkkejä kapitalistisen mentaliteetin juurtumisesta yliopistojen arkeen (Slaughter \& Leslie 2001; Slaughter \& Rhoades 2004; Kauppinen 2010.) Toiset ovat analysoineet akateemista kapitalismia tutkijoiden välisten valtasuhteiden muuttumisen näkökulmasta. Esimerkiksi David Harvie (2000) tarkastelee yliopistoa jakamalla tutkijat tutkimustyöläisiin ja tutkimuskapitalisteihin. Tutkimuskapitalisteilla on enemmän mahdollisuuksia määritellä tehtävää tutkimusta ja hakea hankerahoitusta tutkimustyöläisten joutuessa usein mukautumaan valmiisiin asetelmiin ja täten "myymään” työvoimaansa. Yrityselämässä puhutaan usein osaamisen hankkimisesta työvoiman hankkimisen sijaan. Kapitalistinen logiikka säätelee nuorempien ja kokeneempien tutkijoiden tutkimuksellista liikkumavaraa.

"Et siel on joku henkilö, joka tietää läpikotasin sen tutkimuskentän ja tietää missä ne kontribuution paikat on. Niin mitä kollektiivista täs nyt sitten enää."

"Yksilö tyytyy vaan siihen, et se on vaihdettavissa koko ajan."

Kuten edellisessä lainauksessa yksi meistä kirjoittajista pohtii, akateeminen kapitalismi voi tuottaa sellaista kollektiivisuutta, jossa yksilö kokee olevansa vaihdettavissa oleva työläinen. Laajasti ajateltuna kapitalistisen arvomaailman juurtuminen akateemiseen maailmaan laajenee tarkoittamaan tehokkuutta ja tuottavuutta korostavaa ajattelutapaa. Yksi ajattelutapaan sisältyvä merkittävä rakenteellinen ongelma on hierarkkisuus eli vallan ja tutkimuksellisen pääoman keskittyminen tutkimuskapitalisteille tutkimustyöläisten kustannuksella: pääoma kumuloituu herkästi niiden valtaa pitävien nimiin, joiden tutkimustulokset ja työ ovat helposti tuotteistettavissa, myytävissä ja ostettavissa (Kleinman \& Vallas 2001, 453, 468). Tästä näkökulmasta myös väitöskirjatyön ohjaajan ja ohjattavan välinen suhde on väistämättä hierarkkinen ja jännitteinen valtasuhde, jonka laatu vaikuttaa myös tutkimuksen tekemisen tapoihin.

"Tost tulee mieleen paluu tämmöseen mestari-kisälli-tyyppiseen, et on tyyppi, joka osaa tehä kenkiä ja se tekee niitä tietyllä tavalla ja sit se opettaa kolmellekymmenelle tyypille tavan, millä niitä kenkiä tehdään."

"Paitsi! Se ei tee niitä kenkiä, se vaan hakee rahotusta."

"Sit ne muut tekee, yks tekee nauhat, yks tekee korot, yks leikkaa nahan."

"Sit jostain otetaan harjottelija laittaan ne yhteen. Semmosta pientä poikkeavuutta voi niinkun olla."

"Ja sit ne kaikki kengät, ne ei istu jalkaan, mut se ei haittaa. Sit on jo sosiaalistunut, niin ei haluu ees tehä muuta kuin jatkaa sitä perinnettä."

"Ja sit ne kengät on hiljalleen etääntyny siitä, mitä ihmiset itse asiassa pitää jalassaan, et ne ei sovi kenellekään ja ne kasataan sellaseen helvetinmoiseen varastoon." 
"Ja koska sitä varastoo on paljon, niin se on rahotuksen kannalta hyvä asia, et sitä ei voi ohittaa, koska niit on ihan vimmatusti niitä kenkiä. Juuri kukaan ei edes vilkaise niitä, mutta näyttää hyvältä."

"Koska rahotuksen saamisen yks kriteeri on, et paljon niitä kenkiä on tehty ja sit, et joku muukin on maininnu jossain ne kengät."

"Me voidaan tehdä kenkiä, jotka ei sovi kellekään, mut samaan aikaan niitä kenkiä pitää kuitenkin tehdä ihan hitosti ja jos ihmisen jalat ei mahu niihin, niin se vika on niis ihmisissä."

"Meitsi teki eilen tuol kenkii ja sit mä huomen lennän tonne tekee noit kenkii. Ja sit jos jalat ei sovi niihin kenkiin, niin sit ruvetaan kehittelemä̈̈n tuotteita, että pystytään pienentämään niitä jalkoja.”

Yliopiston rakenteelliset ja hallinnolliset muutokset ovat avanneet tilan ja tarpeen jatkokoulutuksen uudelleenorganisoinnille ja määrittelyille. Samalla entistä markkinaorientoituneemmat toimintatavat ovat alkaneet näkyä jatkokoulutuksen toteuttamisen diskursiivisissa käytännöissä (ks. Kouhia \& Tammi, tulossa). Kyseisissä käytännöissä käydään jatkuvaa neuvottelua väitöskirjaa tekevän tutkijasubjektin paikasta. Mitä muuta väitöskirjaa tekevälle tutkijalle on tarjolla kuin Jussi Vähämäen $(2009,225)$ hahmottelema opportunistin positio, jossa tehdään mitä tahansa, mitä käsketään, mutta jossa "ei ole mitään erityistä annettavaa mihinkään toimintaan, yhteenkään projektiin"? Ja onko akateemisessa kapitalismissa kyse "uudesta" yhteisöllisyydestä, jossa yhteisö toimii kontrollin välineenä ja on "kaikkea muuta kuin vapaa ja viihtyisä, vailla päämääriä olevan yhdessäolon tila, jossa voidaan luottaa tovereihin ja jakaa tietoja ja taitoja” (Vähämäki 2009, 225)?

\section{KOLLEKTIIVISUUDEN UUDELLEEN TARKASTELUA}

"Et me kirjotetaan vuorotellen ja sit siin näkyy ne erilaiset kirjottavat äänet ja siin ei pyritäkään luomaan mitään yhtenäistä vaan et siin kuuluu ne erilaiset ä̈net."
"Ja sit sen kaiken tuolla ulkopuolella liikkumisen näkeminen poliittisena että ei mennä vaan keräämään aineistoa tai tekemään haastatteluu. Et sekin voi olla paikka tehdä jotain ilman et lähtee mistä̈n intervention ajatuksesta tai et on joku valmis suunta mihin pitää mennä."

Tutkimuksen tekeminen on tapahtumasarja, johon vaikuttavat materiaaliset edellytykset (kuten rahoitus), yhteiskunnalliset ja kulttuuriset käsitykset merkittävistä aiheista ja ajankohtaisista ongelmista ja toiset ihmiset, jotka kommentoivat, ohjaavat, vastaavat kysymyksiimme, toimivat "materiaalissamme", hyväksyvät ja hylkäävät kirjoituksiamme. Nämä ihmiset ovat kollegoitamme, ystäviämme, esimiehiämme, tutkimuskohteitamme, lehtien toimittajia ja arvioijia, tutkijoita, joita emme ole koskaan tavanneet, mutta joiden ajatukset ovat meille läheisiä, ja tutkijoita, joiden ajatukset karmivat meitä. Tässä tapahtumasarjassa jokaisen tutkimuksesta tulee myös osa laajempaa yhteiskunnallista verkostoa.

Vaikka moni meistä julkaisee vain omalla nimellään, on kirjoitusten takana monimuotoinen kollektiivisuus. Kirjoittajat (yksinkin kirjoittaessaan) keskustelevat teksteissään toisten tutkijoiden kanssa. Myös laajemmat yhteiskunnalliset virtaukset vaikuttavat kirjoittajaan. Väitämme, että tällaista tiedontuotannon yhteiskunnallisuutta ei voida välttää millään alalla. Kuten feministiset tieteentutkijat ovat tuoneet esiin, myös luonnontieteellinen tieto on yhteiskunnallisten vaikutusten alaista (Irni, Meskus \& Oikkonen 2014; Vaahtera \& Vähäpassi 2014). Mikä muotoillaan ongelmaksi? Mistä oletuksista käsin etsitään ratkaisuja? Miten tutkimusympäristö kojeineen ja oletuksineen muovaa tutkimuksen tuloksia? Luonnontieteelliseen tietoon vaikuttavat myös kulttuuriin ja yhteiskuntaan liitetyt asiat. Oletus siitä, että olisi olemassa puhdas yksilö, joka tuottaisi tietoa yksin riippumatta siitä, nähdäänkö tämä yksilö sankarina (joka selviää yksin) vai uhrina (joka on jätetty syrjään) - ei ota huomioon tiedontuotantoa aina läpäisevää kollektiivisuutta ja yhteiskunnallisuutta. Kollektiivisuutta ei voida vain lisätä tiedontuotantoon, sillä tiedontuotanto ei ole milloinkaan kiinni vain yhdestä yksilöstä. Toisin sanoen kollektiivisesti ja yksilöllisesti tuotettua tietoa ei voida erottaa toisistaan. 
Parhaimmillaan yhdessä kirjoittaminen onkin ollut meille prosessi, joka tekee tiedontuotannon kollektiivisuuden näkyväksi ja työntää yksilösubjektia pois paikoiltaan. Yhdessä kirjoittaminen on parhaimmillaan johtaessaan vieraalle maaperälle, jossa ei enää voi olla aivan varma siitä, mikä oli omaa ja mikä vierasta, tai missä kirjoittava on "minä” ja missä jotain muuta. Meille kollektiivinen kirjoittaminen on ollut antoisaa juuri prosessina, jonka kautta kollektiivisuus tulee näkyväksi ja syntyy. Gilles Deleuze ja Félix Guattari (1987,3) kuvaavat kollektiivisen kirjoittamisen prosessia osuvasti: "Me kaksi kirjoitimme Anti-Oidipuksen yhdessä. Koska kumpikin meistä on useita, se oli jo melkoinen joukko. [...] Emme pyri pisteeseen, jossa ei enää sanota minä, vaan jossa ei enää ole väliä, sanotaanko minä. Emme enää ole itsemme. Jokainen tuntee omansa. Meitä on autettu, inspiroitu ja moninkertaistettu."

Nähdäksemme keskustelun tekijyydestä ei pitäisi pelkistyä siihen, onko tekstillä yksi vai useampi kirjoittaja. Tekijyyttä ei pitäisi myöskään sitoa yhteen yksilöön, sillä tutkijan tietäminen muodostuu muun muassa yhdessä kollegojen, tutkimuksessa mukana olevien sekä tutkijan lukemien tekstien kanssa. Kuitenkin tietokapitalismi pyrkii etsimään akateemisille tuotoksille nimettävät tekijät ja tuotteistamaan yhteistyön (ks. Vähämäki 2009; Paakkari tulossa). Tällöin myös kaikkea tiedontuotantoa läpäisevää kollektiivisuutta pyritään määrittelemään tutkimuskapitalistien eduista käsin, ja kollektiivisuutena nähdään tutkimusjohtajakeskeisyys sekä yhteisjulkaiseminen kansainvälisissä tieteellisissä lehdissä. Vastaavasti tiedontuotanto, jota ei tehdä vahvojen tutkimusjohtajien intressien sanelemina, voi näyttäytyä yksilöllisyytenä.

"Loppujen lopuks tää liittyy siihen, et miten me ymmärretään tiedolla, ajatellaanko me, että tieto kumuloituu ja et me voidaan sit, jaotellaanko niin, että kun kuka hyvänsä vois periaatteessa tehä tän tutkimuksen, et voidaan niinkun replikoida, vai ajatellaanko me, et ne on konflikteja tutkijoiden välillä, et miten se mahtuu kollektiivisuuden vaatimukseen, jossa oletetaan, et tieto kumuloituu."
"Pitää ehkä myöntää, että ulkopuolisen paikkoja ei oo, mut jotain häiritsevii paikkoja vois kyllä löytää."

\section{"Tää on häiritsevää."}

Nykyisissä markkinaorientoituneissa yliopistokäytännöissä ja tutkijan arvon ja laadun määrittelyissä ei aina ole helppoa löytää tilaa tehdä toisin. Julkaise tai katoa, kuten sanotaan. Tämä tarkoittaa monien arjessa sitä, että tutkijan tulee suunnitella tekemisensä siten, että tuottavuus voidaan aina todentaa julkaisujen avulla. Toivomme kuitenkin, että myös tällaisena aikana tutkijat toimisivat kollektiivisesti tavoilla, jotka eivät ole aina siirrettävissä julkaisuluetteloihin.

Näemme, että kasvatustieteellisissä tutkimuskäytännöissä tulisi jättää tilaa myös monografiaväitöskirjoille, yhteiskunnalliselle vaikuttamiselle, monipuoliselle tekemiselle, kehkeytymiselle, vaeltamiselle ja eksymisille. Lisäksi on tärkeää kehittää ja pitää yllä tieto- ja akateemisen kapitalismin rinnalla tiedon ja tietämisen yhteisyyteen (tai yhteisomistajuuteen) perustuvaa ajattelutapaa. Minkälaiset puitteet (rahoitusmalli, journaalit, ym.) tällaisen laajan kollektiivisuuden tunnustamiseksi tarvitaan?

On tärkeää tuoda esiin käytäntöjä, joilla voidaan tehdä tiedontuotannon implisiittistä kollektiivisuutta eksplisiittiseksi. Kollektiivisuudesta puhuttaessa pidämme tärkeänä tuoda esiin keskustellen analysoimisen ja yhdessä kirjoittamisen (ks. Gordon ym. 2000; Lahelma, Lappalainen, Mietola \& Palmu 2014). Yhteisjulkaiseminen ei välttämättä tarkoita sitä, että kaikkien projektin jäsenten ja ohjaajien nimet tulisivat artikkeliin, vaikka painetta indeksien kasvattamiseen onkin. Kollektiivinen malli, jossa sekä seniorit että vertaiset kommentoivat toistensa töitä ja täten jakavat tietokäytänteitä sekä nostavat tutkimusten laatua, on jo laajalti käytössä.

Vaikka pyrimme tässä tekstissä kritisoimaan ja avaamaan akateemisen kapitalismin seurauksia tohtorikoulutettavien ja vanhempien tutkijoiden näkökulmasta, määrittää se kuitenkin toimintaamme myös osana tätä kirjoitusprosessia. Tämä ristiriita tuli näkyväksi, kun keskustelimme siitä, millä tavalla ratkaisemme artikkelin kirjoittajien nimien järjestykseen liittyvät ongelmat: 
"Arvotaan, vedetään järjestys hatusta."

"Miks me ei voida laittaa siihe vaikka, että keksitään joku nimi tälle ryhmälle mikä tän kirjottaa ja sit se on niinku se kirjottaja ja sit suluissa ilmoittaa nimet aakkosjärjestyksessä tai nimet arvottu. Paitsi sit jos joku tekee ihan helvetinmoisen työn yksin, niinku et kirjottaa sen auki."

"Tapellaan siitä sitten."

"Eiks sitä voida olla oikeen radikaalia ja sanoo seminaarin nimen tai sitten, että nä̈̈ ihmiset oli mukana seminaarissa. Sillä menee vastoin kaikkea tätä... Mä en tiedä, onks se mahollista."

"Mietitään tätä nimien käyttöä nyt viel kuitenkin, koska tää on varmaan semmonen juttu, mihin ehkä me toivotaan, et viitataan."

"Se on toisaalt sen järjestelmän hyödyntämistä."

"Samaa riitaa, mitä kritisoidaan tässä."

Ulkopuolisen paikkoja ei ole.

\author{
Hanna Guttorm \\ Auli Arvola-Orlander \\ Anna-Maija Niemi \\ Elina Vaahtera \\ Katariina Mertanen \\ Tuure Tammi \\ Sari Mononen-Batista Costa \\ Kristiina Brunila \\ Anna Kouhia \\ Antti Paakkari \\ Ville Kainulainen \\ Elina Ikävalko
}

Kirjoittajat ovat kasvatustieteen tutkijoita, tohtorikoulutettavia ja "jo tohtoriksi koulutettuja", Helsingin yliopiston Käyttäytymistieteiden laitokselta ja Opettajankoulutuslaitokselta sekä niiden liepeiltä. He kutsuvat itseään KYK-kollektiiviksi IKasvatus, yhteiskunta, kulttuuri). Kirjoittajajärjestys on arvottu.

\section{LÄHTEET}

Brunila, K. (2011). Rönsyt pois. Tutkija tietokykykapitalismissa. Aikuiskasvatus 31(2), 111-119.

Brunila, K. \& Ikävalko, E. (2012). Vallan tunnistaminen siihen lamaantumatta: näkökulmia diskursiivisdekonstruktiiviseen lukutapaan. Politiikka 54(4), 285-300.

Deleuze, G. \& Guattari, F. (1987). A Thousand Plateaus. Translated by Brian Massumi. New York: University of Minnesota Press.

Derrida, J. (1997). The Villanova Roundtable. A Conversation with Jacques Derrida, in John Caputo Deconstruction in a nutshell. A Conversation with Jacques Derrida. New York: Fordham University Press.

Derrida, J. (2003). Platonin apteekki ja muita kirjoituksia. Toim. Teemu Ikonen \& Janne Porttikivi. Käänt. Teemu Ikonen ym. (Alkuper. tekstit 1967-1972.) Helsinki: Gaudeamus.

Gordon, T., Holland, J. \& Lahelma, E. (2000). Making spaces. Citizenship and difference in schools. London: McMillan \& New York: St Martin's Press.

Guttorm, H. (2014). Sommitelmia ja kiepsahduksia: Nomadisia kirjoituksia tutkimuksen tulemisesta (ja käsityön sukupuolisopimuksesta).

Kasvatustieteellisiä tutkimuksia 252. Helsinki: Helsingin yliopisto.

Hakala, K. (2007). Paremmin tietäjän paikka ja toisin tietämisen tila: opettajuus (ja tutkijuus) pedagogisena suhteena. Kasvatustieteen laitoksen tutkimuksia 212. Helsinki: Helsingin yliopisto.

Hakkarainen, K., Hytönen, K., Makkonen, J. \& Lehtinen, E. (2013). Kollektiivista mallia voidaan soveltaa kasvatustieteiden tohtorikoulutuksessa. Aikuiskasvatus 33(4), 277-289.

Harvie, D. (2000). Alienation, Class and Enclosure in UK Universities. Capital \& Class 71, 103-132.

Irni, S., Meskus, M. \& Oikkonen, V. (2014). Teknotieteen, sukupuolen ja materiaalisuuden muunnelmat. Teoksessa S. Irni, M. Meskus \& V. Oikkonen (toim.) Muokattu elämä: teknotiede, sukupuoli ja materiaalisuus. Tampere: Vastapaino, 7-47.

Kauppinen, I. (2010). Akateeminen kapitalismi aineettoman omaisuuden haltuunottamisena. Tiedepolitiikka 35(2), 17-32.

Kleinman, D.L. \& Vallas, S.P. (2001). Science, capitalism, and the rise of the 'knowledge worker': the changing structure of knowledge production in the United States. Theory and Society 30 (2001), 451-492. 
Kouhia, A. \& Tammi, T. (tulossa). Akateeminen kapitalismi ja uudistuvat tohtorikoulutuksen käytännöt jatko-opiskelijan arjessa. Arvioitavana julkaisussa Kasvatus ja Aika.

Lahelma, E., Lappalainen, S., Mietola, R. \& Palmu, T. (2014). Discussions that 'tickle our brains': constructing interpretations through multiple ethnographic data-sets. Ethnography and Education, 9(1), 51-65.

Nichols, S.L. \& Berliner, D.C. (2007). Collateral Damage: How High-Stakes Testing Corrupts America's Schools. Cambridge, MA: Harvard Education Press.

Paakkari, A. (tulossa). Koulu ja kännykät. Tietokykykapitalismi luokkahuoneessa. Teoksessa K. Brunila, J. Onnismaa \& H. Pasanen (toim.) Tietokykykapitalismi. Aikuiskasvatuksen 52. vuosikirja. Aikuiskasvatuksen tutkimusseura ja Kansanvalistusseura.

Puuska, H-M. \& Miettinen, M. (2008). Julkaisukäytännöt eri tieteenaloilla. Opetusministeriön julkaisuja 2008:33. Opetusministeriö, Koulutus- ja tiedepolitiikan osasto.

Slaughter, S. \& Leslie, L. (1997). Academic Capitalism. Politics, Policies and the Entrepreneurial University. Baltimore \& London: The John Hopkins University Press.

Slaughter, S. \& Rhoades, G. (2004). Academic Capitalism and the New Economy. Markets, State and Higher Education. Baltimore \& London: The John Hopkins University Press.

Vaahtera, E. \& Vähäpassi E. (2014). Vammaisuuden haluaminen ja kulttuuriset normit. Teoksessa S. Irni, M. Meskus \& V. Oikkonen (toim.) Muokattu elämä: teknotiede, sukupuoli ja materiaalisuus. Tampere: Vastapaino, 233-263.

Valo, M. (2013). Monografia vai artikkeliväitöskirja? Yliopistopedagogiikka - Journal of University Pedagogy 20(1), 25-27. Haettu 2.3.2014 osoitteesta http://lehti. yliopistopedagogiikka.fi/2013/04/08/monografia-vaiartikkelivaitoskirja/

Vähämäki, J. (2009). Itsen alistus. Työ, tuotanto ja valta tietokykykapitalismissa. Helsinki: Like.

\section{VIITTEET}

1 Kiinnostavasti Hakkarainen ym. $(2013,287)$ tunnustavat: "Monista vahvuuksistaan huolimatta kollektiivinen malli ei siis automaattisesti tuota opiskelijaa tukevia prosesseja [...] tai merkitse sitä, että tutkimus olisi yksilöllistä mallia korkeatasoisempaa." 